\title{
Physical and Numerical Modelling of Tsunami Run-up on Seawall at Sloping Beach
}

\author{
Ma'ruf Hadi Sutanto \\ Coastal Research and Development Center, Ministry of Public Works and Public Housing, INDONESIA \\ maruf82211@gmail.com
}

SUBMITTED 25 February 2019 REVISED 29 March 2019 ACCEPTED 24 April 2019

\begin{abstract}
Tsunami run-up on land has a large destructive power. Further studies are deemed necessary to understand the process and characteristics of tsunami run-up in coastal areas. Seawall structures can reduce the run-up of a tsunami depending on the height of the seawall crest. Physical modeling shows that seawall may significantly reduce run-up $(R)$ and inundation $\left(X_{i}\right)$. The highest reduction up to $55 \%$ where the seawall peak height is $7 \mathrm{~cm}$ and the water depth is $15 \mathrm{~cm}$. With the same scenario in numerical modeling, the percentage reduction is $67.53 \%$. The highest inundation $\left(X_{\mathrm{i}}\right)$ in the scenario without seawall structure is $6.081 \mathrm{~m}$ when the initial water depth $\left(\mathrm{d}_{0}\right)$ equals to $30 \mathrm{~cm}$. The result of the numerical model for the same scenario is $6.970 \mathrm{~m}$. Seawall as tsunami mitigation structure is only effective when the tsunami wave is relatively low compared to the seawall height $\left(\mathrm{H} / h_{\mathrm{sw}}\right)$. Reduction percentage $>25 \%$, with conditions that $\mathrm{H} / h_{\mathrm{sw}}$ is $<0.856$ (physical model) and $<0.802$ (numerical model).
\end{abstract}

KEYWORDS Run-up; Tsunami; TUNAMI; Physical model; Numerical model

(C) The Author(s) 2018. This article is distributed under a Creative Commons Attribution-ShareAlike 4.0 International license.

\section{INTRODUCTION}

Coastal areas are potential for development. There are many large coastal areas and small islands in Indonesia. At present, the government is intensifying the program of coastal area development; however, some areas are very vulnerable to natural disasters, especially the tsunami disaster that is closely related to coastal areas. Indonesian Law no. 26 of 2007 states that geographically, Republic of Indonesia lies in a disaster-prone area, thus, as an effort to improve the safety and comfort of life and livelihood, a spatial planning based on disaster mitigation is required.

The center of urban development in several parts of the world, including in Indonesia, is mostly located in coastal areas, so the rapid development makes the risk to disasters also increases (Parwanto and Oyama, 2014). Indonesia is a country prone to tsunami, especially its coastal areas that are directly heading to the meeting of Eurasian, Indo-Australian and Pacific Plates, including the western part of Sumatra Island, south of Java, Nusa Tenggara, northern part of Papua, Sulawesi and Maluku, and eastern part of Kalimantan Island (Figure 1). Based on historical records, large tsunami events also occurred in the Territory of Indonesia (Suppasri, et al., 2012). The movement of the main plates around the Indonesian region mostly causes the events (Bock et al., 2003).
Since the Sumatra tsunami in 2004 and Tohoku tsunami in 2011, various structural and non-structural mitigation efforts have been carried out by many countries with high levels of vulnerability to tsunami. They create a network of cooperation in establishing inter-state mitigation systems and policy determination (Løvholt et al., 2014; StrusińskaCorreia, 2017; White and Haughton, 2017; Nakaya et al., 2018; Naylor, Walker and Suppasri, 2018; Pile et al., 2018). The accuracy of the estimated time of arrival (estimated time or arrival - ETA) of the tsunami wave is also important to determine the type of mitigation suitable to the risky area (Wang, 2015).

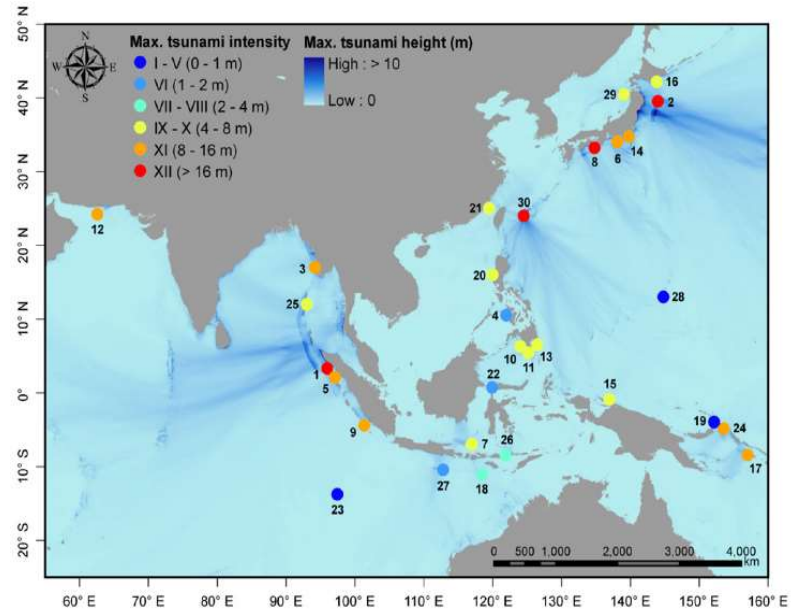

Figure 1. Maximum tsunami height from the simulation of 30 large tsunami events (Suppasri et al., 2012) 
Structural mitigation efforts, such as hard protection to resist tsunami, include building breakwaters, seawalls, groins, and coastal parallel breakwater structures. As an effort to protect residential areas and/or public facilities with high levels of development and are very close to the coastline, seawall structures can be used (Triatmodjo, 2006).

The effectiveness of seawall built in some parts of Japan, became a big concern as a lesson learnt from the 2011 tsunami incident due to its severe impact (Raby et al., 2015). Figure 2 shows the ratio of damage caused is very much significant for seawall with a height of 5 $\mathrm{m}$, and the damage ratio decreases when seawall height $>5 \mathrm{~m}$ (Nateghi et al., 2016).

Several studies developed various methods for modeling tsunami characteristics, ranging from generation, propagation and run-up processes on land (Yeh, 1991; Benazir, Triatmadja, R., Raharjo, A. P. \& Yuwono, 2016; Sriram et al., 2016; Tomiczek et al., 2016). Since 2004, more research groups have developed new methods for tsunami modeling, or adapted hydrodynamic codes that were originally developed for other purposes (Cummins, Kong and Satake, 2008).

Research of tsunami characteristics through modeling also increases the accuracy of vulnerability and risk assessments of an area upon the tsunami disaster, so that it is useful as a part of disaster mitigation. It is important to carry out validation and verification of each modeling used for assessing or forecasting tsunami hazard systems (Synolakis et al., 2008). Each modeling will be optimum if validated and verified based on the field conditions, or by establishing physical modeling based on limited field data as an effort to represent the field conditions.
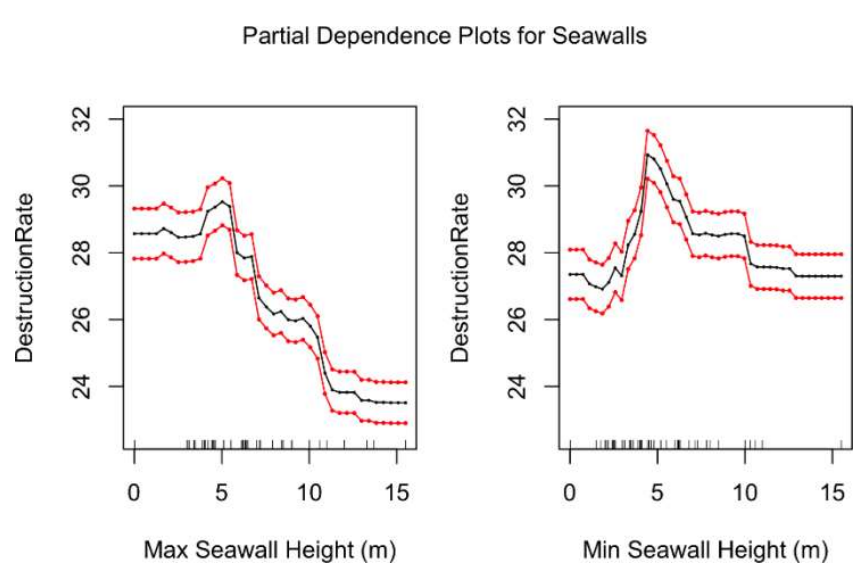

Figure 2. The Partial Relationship between maximum and minimum height of Seawall and the Damage Ratio. The red lines represent bootstrapped confidence intervals around model estimates (Nateghi et al., 2016)
Based on factors as mentioned above, the objective of this study was to examine the run-up characteristics and tsunami inundation on a sloping beach by using seawall as a mitigation structure, through laboratory testing and numerical modeling. Physical modeling in the laboratory was carried out to verify the numerical modeling.

\section{LITERATURE REVIEW}

\subsection{The Characteristics of a Tsunami Wave}

Tsunami characteristics as explained by Bryant (2014) is as such as wind waves that it has wavelength (L), period (T), water depth (d), and also can experience shoaling, refraction and diffraction. Tsunami waves differ from other types of waves. According to Holthuijsen (2010), they are produced by landslides or underwater earthquakes and bring a damaging effect. Tsunami waves are difficult to predict and almost invisible in the open ocean, because they have low amplitude, but can increase their amplitude when approaching the coast. This brings severe disaster on coastal areas with no readiness response.

\subsection{Tsunami Wave Modelling}

The numerical method of the tsunami was initially introduced by Goto and Ogawa in 1982. It modeled tsunami propagation near the coast from the source until the run-up event on the coastline (Benazir, Triatmadja, R., Raharjo, A. P. \& Yuwono, 2016). The model resolves the nonlinear form of long wave equations together with base friction with finite difference methods and calculates water surface fluctuations and average depth velocities on each location (Imamura, Yalciner and Ozyurt, 2006). The regulator equation can be written in the following Cartesian coordinates.

$\frac{\partial \eta}{\partial t}+\frac{\partial M}{\partial x}+\frac{\partial N}{\partial y}=0$

$\frac{\partial M}{\partial t}+\frac{\partial}{\partial x}\left(\frac{M^{2}}{D}\right)+\frac{\partial}{\partial y}\left(\frac{M N}{D}\right)+g D \frac{\partial \eta}{\partial x}+\frac{\tau_{x}}{\rho}=0$

$\frac{\partial N}{\partial t}+\frac{\partial}{\partial x}\left(\frac{M N}{D}\right)+\frac{\partial}{\partial y}\left(\frac{N^{2}}{D}\right)+g D \frac{\partial \eta}{\partial y}+\frac{\tau_{y}}{\rho}=0$

$D=h+\eta$ is the total water depth, where $h$ is static water depth and $\eta$ for the water surface elevation. $M$ and $N$ are the flux velocities of the $\mathrm{x}$ and $\mathrm{y}$ directions, namely:

$M=\int_{h}^{\eta} u d z=u(h+\eta)=u D$

$N=\int_{h}^{\eta} v d z=v(h+\eta)=v D$

As for the base friction, it is generally expressed by the following equation. 
$\frac{\tau_{x}}{\rho}=\frac{1}{2} \frac{f}{D^{2}} M \sqrt{M^{2}+N^{2}}$

$\frac{\tau_{y}}{\rho}=\frac{1}{2} \frac{f}{D^{2}} N \sqrt{M^{2}+N^{2}}$

where $f$ is the friction coefficient. The $f$ value refers to the use of Manning ( $n$ ) roughness. The relationship between $f$ and $n$ is:

$=\sqrt{\frac{f D^{1 / 3}}{2 g} \rightarrow f=\frac{n^{2} 2 g}{D^{1 / 3}}}$

The equation states that $f$ roughness becomes large when the total depth $D$ is small when $n$ is constant. Thus, the basic form of friction is expressed by:

$\frac{\tau_{x}}{\rho}=\frac{g n^{2}}{D^{7 / 3}} M \sqrt{M^{2}+N^{2}}$

$\frac{\tau_{y}}{\rho}=\frac{g n^{2}}{D^{7 / 3}} N \sqrt{M^{2}+N^{2}}$

\section{RESEARCH METHOD}

Physical modeling is carried out in the Hydraulics and Hydrology Laboratory, Center for Engineering Studies, Gadjah Mada University Yogyakarta. The wave flume dimension was $15.90 \mathrm{~m}$ of length, $0.60 \mathrm{~m}$ of width and $0.44 \mathrm{~m}$ of height (Figure 3 ). Channels were equipped with tsunami wave generators completed with dam break method, and overflow tubs in the upstream and downstream sections of the channel. Model preparation begins by determining the scale of the model which is affected by the dimensional capacity of the wave flume. The upstream part is a reservoir with a length of $4 \mathrm{~m}$, as a source of tsunami generation, the downstream part is a sloping beach model. 1:20 sloping beach model slope is used based on wave flume capacity.

The physical modeling of tsunami run-ups in the laboratory has been carried out such as (Yeh, Ghazali and Marton, 1989; Yeh, 1991; Triatmadja and Nurhasanah, 2012; Benazir, Triatmadja, R., Raharjo, A. P. \& Yuwono, 2016), and others. In some of these studies, the simulation of the generation of tsunami waves used a dam break model, as in Benazir, Triatmadja, R., Raharjo, A. P. \& Yuwono (2016). Under this method, the generation of tsunamis produced surge waves as in tsunami events that reach the coast / land.

Most wave models scale the wave parameters and beach/coastal structure dimensions following the Froude scaling criterion, such models should not be distorted, and should be scaled down linearly (Arana, 2017). Froude similarity is especially suited for models where friction effects are negligible (e.g. deep-water wave propagation) or for short, highly turbulent phenomena (e.g. hydraulic jump) since the energy dissipation of the latter depends mainly on the turbulent shear stress terms (Heller, 2011).

Testing the run-up characteristics of tsunami waves on sloping beach and seawall models was started by determining the tsunami wave-based generation scenario and dam break. The scenario consisted of variation in reservoir depth $\left(\mathrm{d}_{0}\right)$ and seawall crest height. Each scenario was tested 3 (three) times. Reservoir depth variations $\left(d_{0}\right)$ were $0.150 \mathrm{~m}, 0.200 \mathrm{~m}$, $0.250 \mathrm{~m}$ and $0.300 \mathrm{~m}$, and variations in sea wall height $\left(h_{\mathrm{sw}}\right)$ were $3 \mathrm{~cm}, 5 \mathrm{~cm}$ and $7 \mathrm{~cm}$. The distance of the seawall structure model $x_{\mathrm{sw}}=0.5 \mathrm{~m}$, and the initial downstream depth was $d_{1}=0.05 \mathrm{~m}$.

Data of tsunami wave height and period were measured using a Water Tide Meter WTM-800 (DNTech), 4 capacitance wave gauges, with the material type is Stainless Steel 304 and PTFE String AWG 30. Water level fluctuations were measured and data series recorded by using the data acquisition software. The frequency of data retrieval in 1 second would take 14 data (sampling rate $14 \mathrm{~Hz}$ ). The position of each sensor from the gate reservoir is $\mathrm{wp} 1=2.0 \mathrm{~m}$, wp $2=3.0 \mathrm{~m}$, $\mathrm{wp} 3=4.0 \mathrm{~m}$, wp $4=5.0 \mathrm{~m}$. Digital cameras are also used for visual documentation to observe the propagation of tsunami waves in shallow water and when reaching maximum inundation on sloping beach model. Two cameras are placed on top of the model and on the side of the model (Sony A6000).

Numerical modeling process for obtaining the tsunami run-up characteristics used the TUNAMI Modified Program (Benazir, 2016), a modification of the TUNAMI model developed by Goto et al.(1992) and Imamura, Yalciner and Ozyurt (2006). Such numerical modeling process was through the stages of the initial process (pre-processing), in the form of making input files as boundary conditions. Initial data consisted of topographic and bathymetry data, based on the wave channel conditions used in the physical models. Determining the depth of the reservoir as the initiation of the formation of a tsunami wave, also determined the required output parameters. 

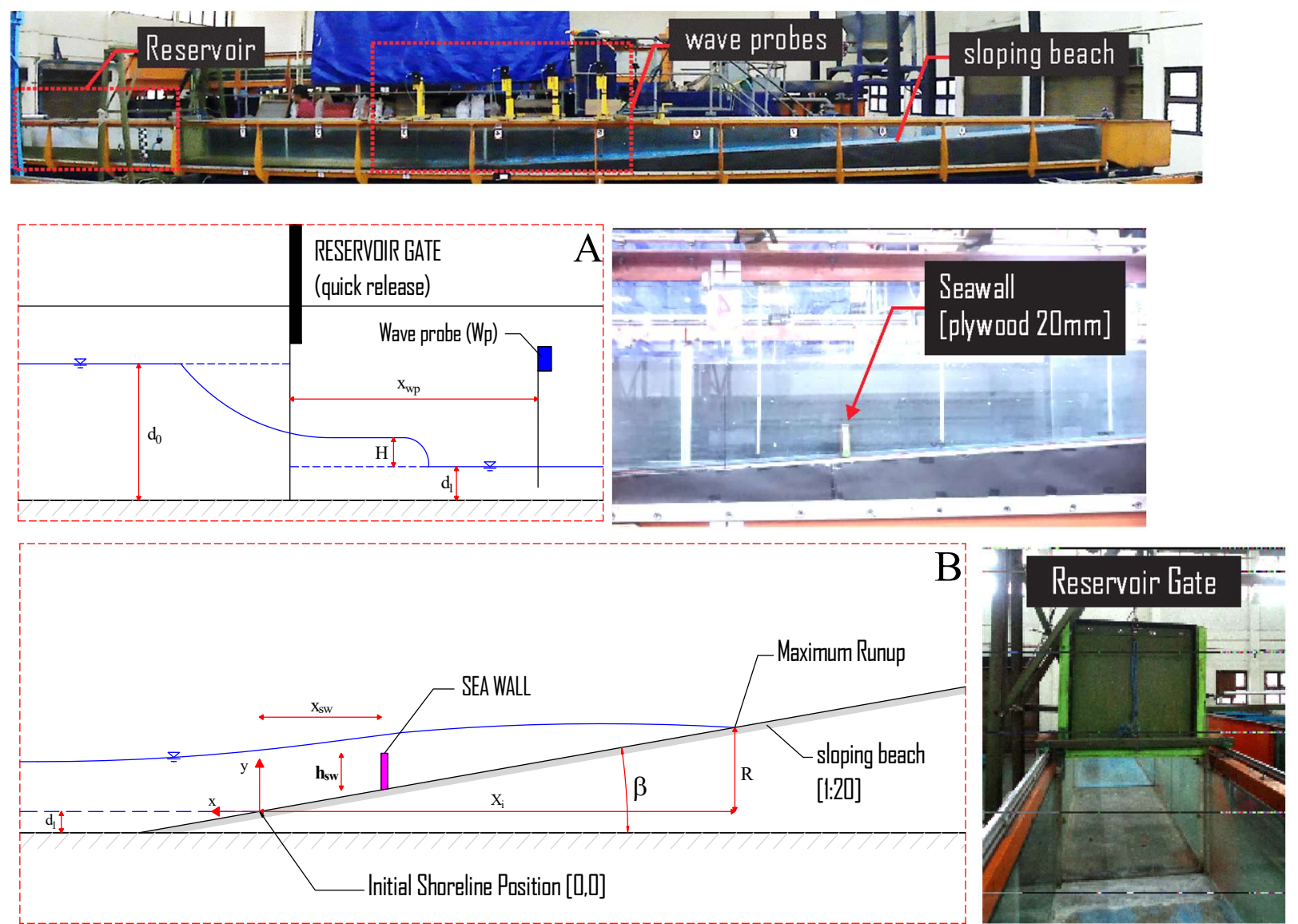

Figure 3. Laboratory test setups and variables used in the modeling. The upstream part is a reservoir with a length of $4 \mathrm{~m}$ (a), the downstream part is a sloping beach model (b)

The determination of the size of the spatial grid affected the level of accuracy of modeling. However, it also affected the time needed to process the model. Numerical modeling with the spatial grid used was 0.01 $\mathrm{m}$, so that the dimensions of the channel were made as the topographic and bathymetric data, using the number of grids in the $\mathrm{x}$ axis by 1501 grids and the $\mathrm{y}$ axis by 61 grids. The data also accommodated the conditions of the reservoir, depth in the downstream/d1 (initial downstream depth) and sloping beach. Manning coefficient value was 0.012 , which represented the material based on the beach model from plywood (Benazir, Triatmadja, R., Raharjo, A. P. \& Yuwono, 2016)

\section{RESULT AND DISCUSSION}

\subsection{Physical Modeling in the Laboratory}

The laying of the seawall model on the sloping beach was used as an obstacle to the tsunami waves on its propagation to the land. This condition affected the reduction of wave energy when interacting with the building model, to reduce the height and distance fof the run-up inundation.
Testing of the sloping beach scenario without seawall structure was carried out in each scenario. Figure 4 shows a physical modeling scenario with $\mathrm{d}_{0}=0.30 \mathrm{~m}$ without a seawall model. The shape of the tsunami wave can be seen as fully developed bore propagation (Yeh, Ghazali and Marton, 1989) when in constant waters $\left(\mathrm{d}_{1}=0.05 \mathrm{~m}\right)$, and after reaching the transitional waters until run-up process on artificial beach slope.

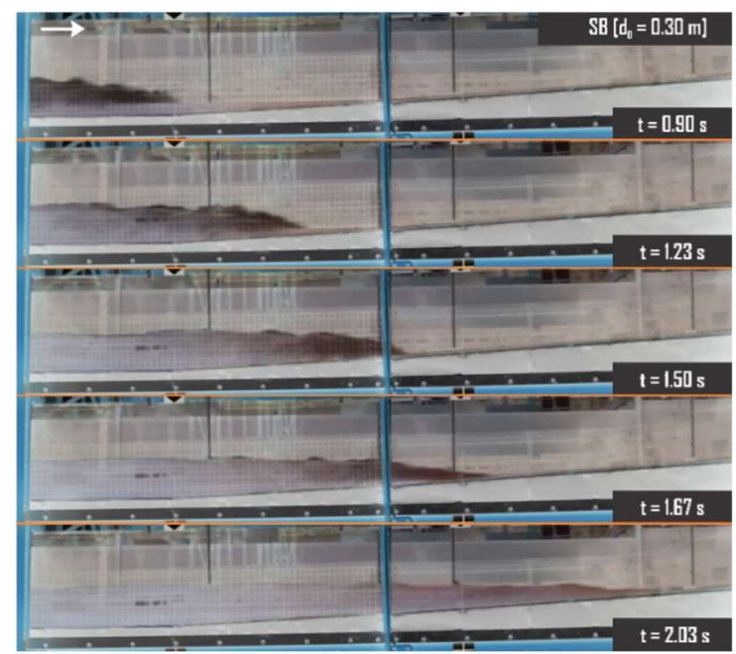

Figure 4. Observation of tsunami wave propagation on wave flume, sloping beach scenario $\mathrm{d}_{0}=0.30 \mathrm{~m}$ without seawall model 
Figure 5 presents a snapshot of the interaction process of the tsunami wave run-up with the seawall and variations of height $\left(h_{\mathrm{sw}}\right): 0.03 \mathrm{~m}, 0.05 \mathrm{~m}$ and $0.07 \mathrm{~m}$, placed at a distance of $x_{\mathrm{sw}}=0.50 \mathrm{~m}$ and $\mathrm{d}_{0}=0.30 \mathrm{~m}$. Tsunami waves that hit the seawall were reflected and created a damaging effect, and a moment later overflowed the downstream of seawall.

Scenario which set the seawall height of $0.07 \mathrm{~m}$ cause a tidal wave higher than scenario of seawall height of $0.03 \mathrm{~m}$ and $0.05 \mathrm{~m}$. The seawall height of $0.07 \mathrm{~m}$ creates earlier increasing process and the longer stay at the peak level. The interaction process of tsunami run up were fluctuated which can be observed from the experiement result presented in Figure 5.

Figure 6 shows the visual analysis results of the Runup Inundation Distance $\left(\mathrm{X}_{\mathrm{i}}\right)$ to the depth of the reservoir $\left(\mathrm{d}_{0}\right)$, indicating the test scenario for the sloping beach model before seawall model was installed. The test was carried out by adding a seawall model on the slope of the beach at a distance of laying seawall from the coastline (initial downstream), $\mathrm{xsw}=$ $0.50 \mathrm{~m}$. The height of tsunami inundation (R) was analyzed based on the maximum inundation distance obtained from the water level. Figure 7 shows that the seawall model was capable of reducing the height of the tsunami inundation (R) from the propagation of tsunami waves along the wave flume.

Figure 8 shows the results of tsunami wave height fluctuations measurements with WTM, in the form of water level fluctuations at a distance $4 \mathrm{~m}$ from gate (Wp.2) from the reservoir gate or before the seawall model. This can be seen from the seawall model on the sloping beach, making the wave height higher at the seawall upstream. This condition occurred because the upstream water level of the model rises due to the existence of the seawall holding the wave and so it overflows on the surface of the seawall model.

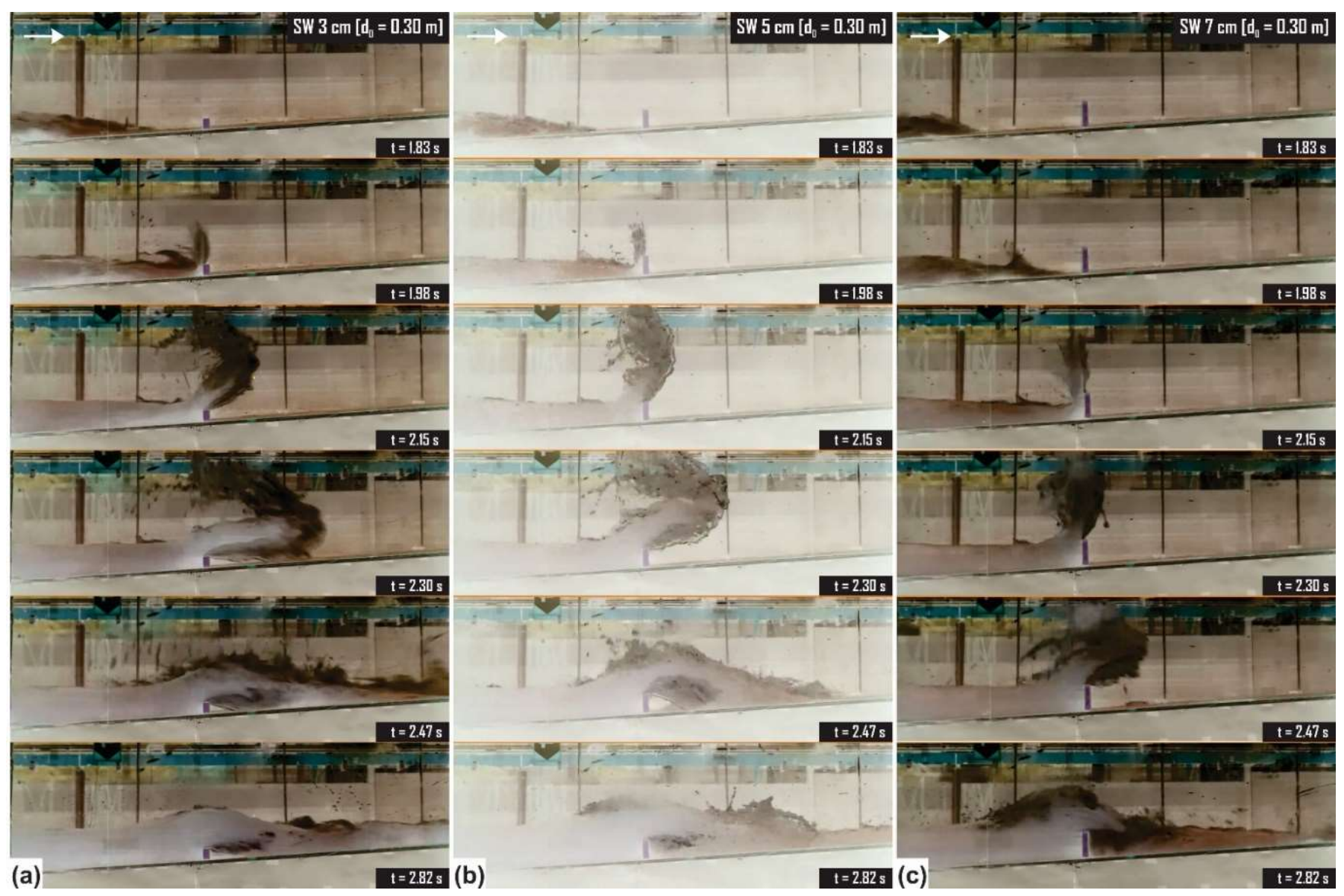

Figure 5. Interaction process of tsunami wave run-up with seawall, variation in seawall height $\left(h_{\mathrm{sw}}\right)$ of $0.03 \mathrm{~m}(\mathrm{a}), 0.05 \mathrm{~m}(\mathrm{~b})$ and $0.07 \mathrm{~m}(\mathrm{c})$, and placed at a distance of $\mathrm{Xsw}_{\mathrm{sw}}=0.50 \mathrm{~m}$. 


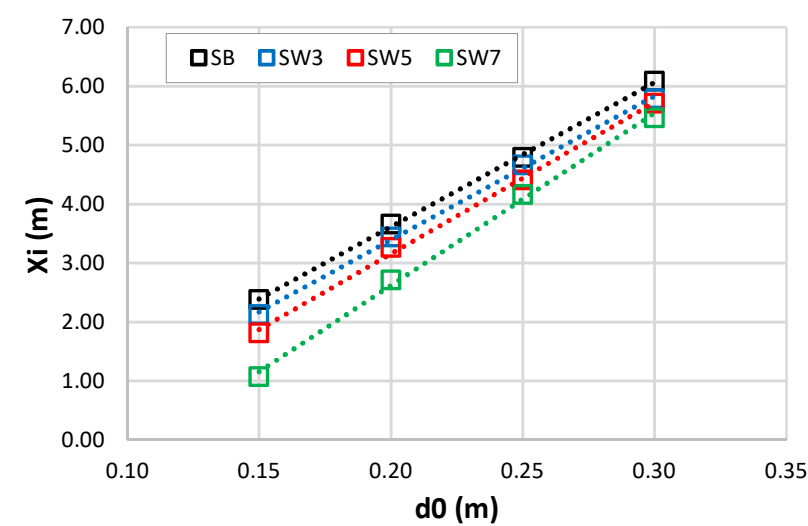

Figure 6. Results of visual analysis of run-up inundation distance $\left(X_{i}\right)$, reservoir depth ( $\left.d_{0}\right)$

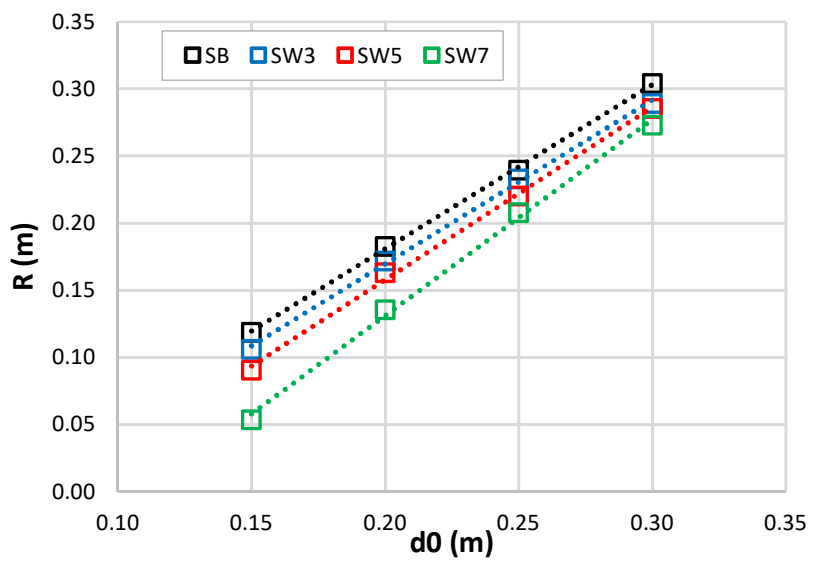

Figure 7. Analysis results of the height of run-up inundation $(\mathrm{R})$, reservoir depth $\left(\mathrm{d}_{0}\right)$

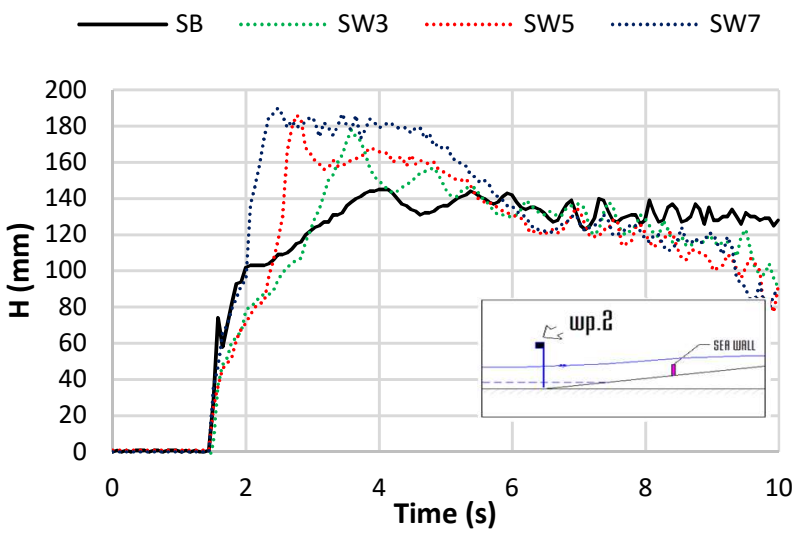

Figure 8 Measurement of wave height fluctuations, the position of wave probe is $x w p=3.0 \mathrm{~m}$, Scenario $d_{0}=0.30 \mathrm{~m}$ (upstream seawall)

\subsection{Numerical Modeling}

Tsunami wave profiles based on the numerical simulation results is presented in Figure 9 and Figure 10. It can be seen that the process of tsunami wave propagation was shortly after the wave generation, and when it reached the coastline, the tsunami run-up puddled at maximum point. The wave profile picture showed fluctuations of water level (y-direction). In order to have more visible appearance of the tsunami wave, the wave profile image picture is presented in different scales between $\mathrm{x}$-direction and $\mathrm{y}$-direction.
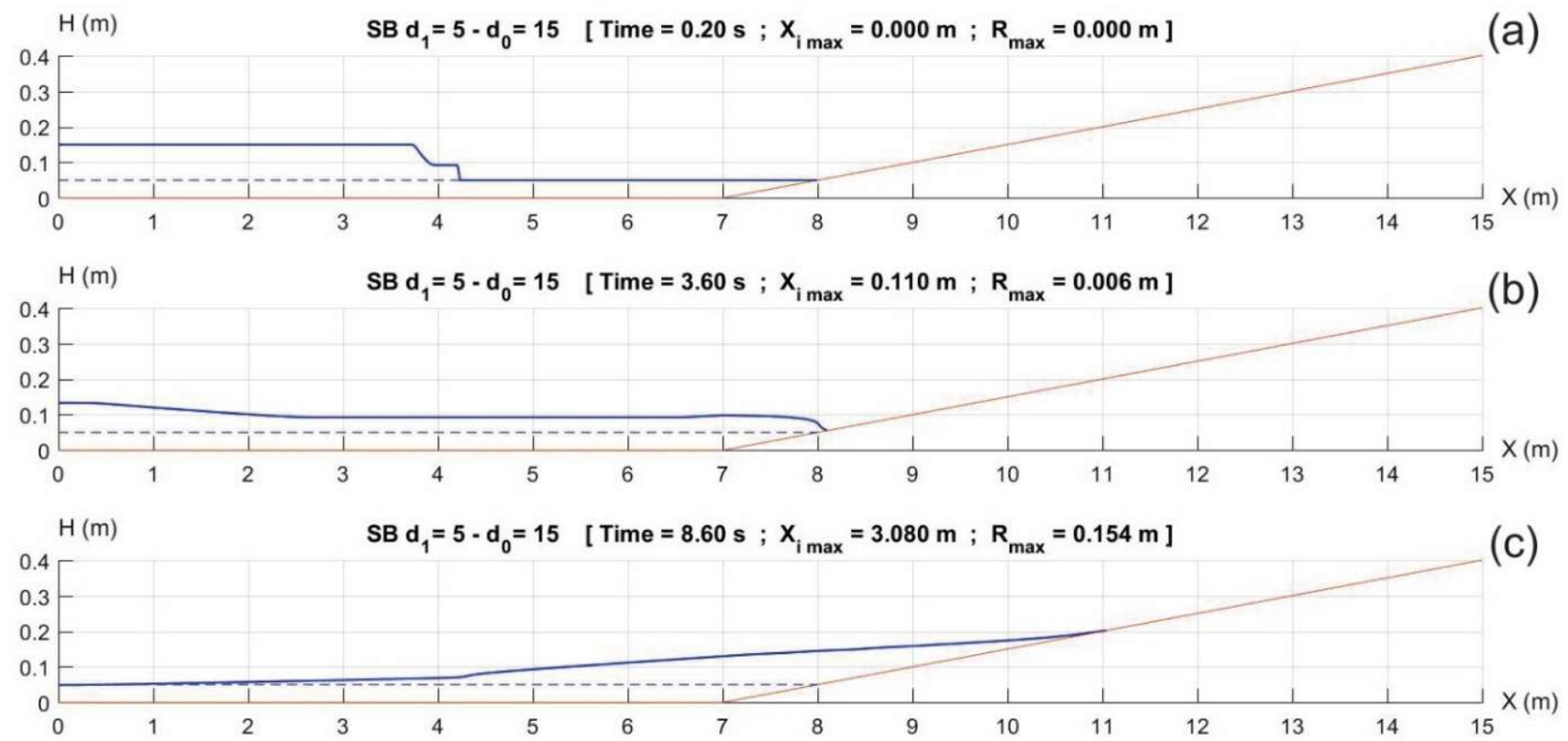

Figure 9. Tsunami waves profile with the scenario $d_{1}=5 \mathrm{~cm}$ and $d_{0}=15 \mathrm{~cm}$, on the sloping beach model. three conditions are shown: shortly after the wave is generated (a), bore approaching the shore (b) maximum inundation (c). 

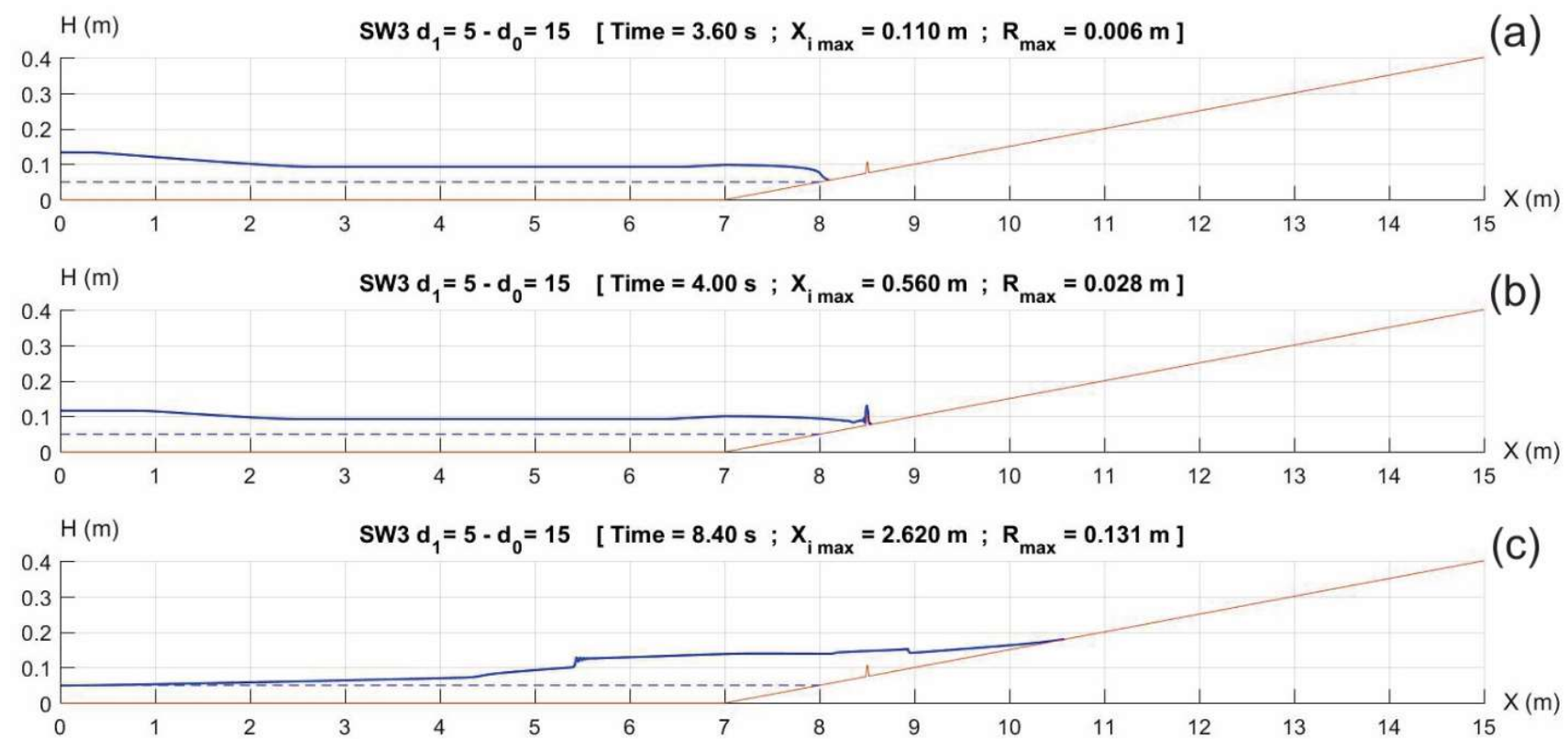

Figure 10. Tsunami waves profile with the scenario $\mathrm{d}_{0}=15 \mathrm{~cm}$, on the sloping beach model and seawall height $h_{\mathrm{sw}}=3 \mathrm{~cm}$. three conditions are shown: bore approaching the shore (a), bore hit the seawall (b) and when the maximum inundation (c).

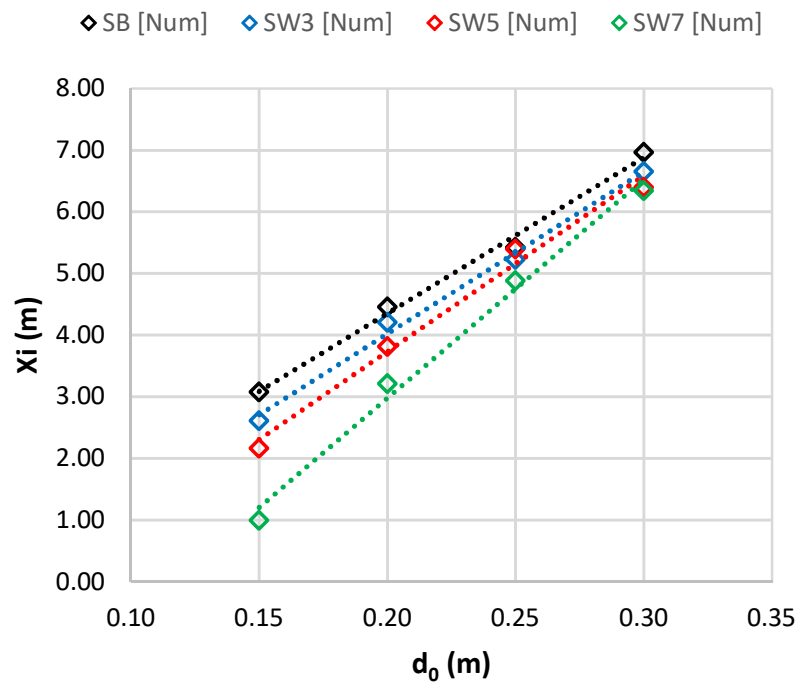

Figure 11. Tsunami inundation distance $\left(X_{i}\right)$ for each numerical modeling scenario

Figure 11 shows the maximum tsunami inundation distance for of the tsunami run-up $\left(X_{i}\right)$ for each numerical modeling scenario each numerical modelling scenario. The greater the value of the reservoir depth $\left(d_{0}\right)$, the distance from the tsunami run-up would also be further away. The farthest distance of the range was seen in the scenario when the value of $d_{0}=30 \mathrm{~cm}$. Run-up almost reached the end of the beach slope model.

\subsection{The Effectiveness of Seawall as the Tsunami Mitigation Structure}

The seawall ability on redycing the range of tsunami run-up depends on the height of the seawall. The reduction value was obtained from the difference between the maximum run-up height $\left(\mathrm{R}_{\max }\right)$ before and after the seawall, with some variations in seawall height. Figure 12 shows the seawall model was capable of reducing distance $\left(\mathrm{X}_{\mathrm{i}}\right)$ and the height of the tsunami run-up inundation $(\mathrm{R})$ on the slope of the coast. The highest reduction was when seawall model was $7 \mathrm{~cm}$ with $\mathrm{d}_{0}=0.15 \mathrm{~m}$, the percentage of reduction was up to 55\% (physical model) and 67.53\% (numerical model).

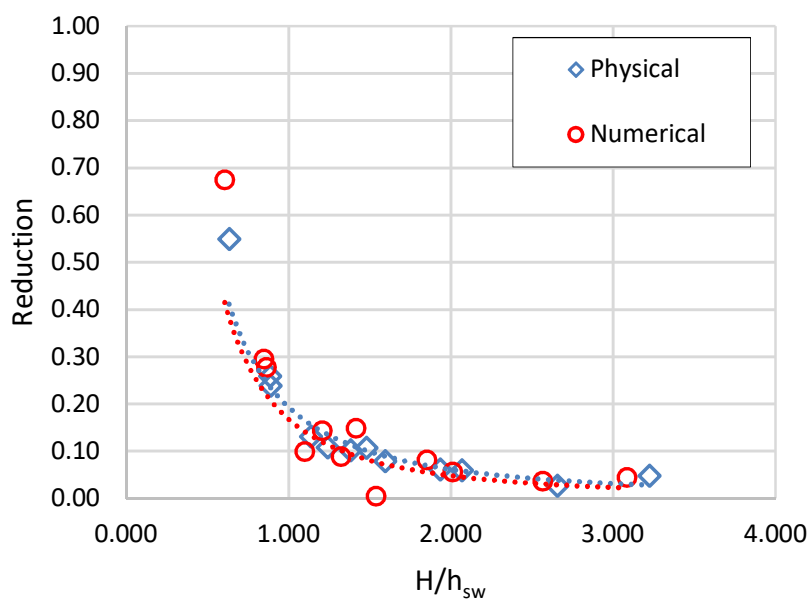

Figure 12. Reduction of run-up inundation range $\left(X_{i}\right)$ from the physical models and numerical models.

The trend shown in the graph is that the reduction value was extensive when the height of the tsunami wave was not too high, and when the model scenario used the seawall with a peak height of $7 \mathrm{~cm}$. The greater the value of $\mathrm{H} / h_{\mathrm{sw}}$, which was when the seawall peak height conditions were lower or the tsunami wave 
height generated from the initiation of the reservoir depth $\left(\mathrm{d}_{0}\right)$ was higher, then the reduction obtained was smaller. Seawall as tsunami mitigation structure is only effective when the tsunami wave is relatively low compared to the seawall height $\left(\mathrm{H} / h_{\mathrm{sw}}\right)$. Reduction percentage $>25 \%$, required that $\mathrm{H} / h_{\text {sw }}<0.856$ (physical model) and $<0.802$ (numerical model). This shows that the seawall heights is only effective on tsunami waves which are not too large compared to the height of the seawall structure. The roughness coefficients still play an important role in determining the maximum inundation, which might be the cause of differences between numerical and physical results.

\section{CONCLUSION}

In tsunami generation based on the dam break, the height and speed of the tsunami depended on the height of the water in the reservoir, which represented the height of the tsunami $(\mathrm{H})$ on the physical model that was larger than the numerical model. The highest reduction occurred when the seawall model with the crest elevation of $0.07 \mathrm{~m}$ and $\mathrm{d}_{0}=15 \mathrm{~cm}$. The percentage of reduction reached $55 \%$ in physical models and $67.53 \%$ in numerical models. The tendency of the reduction value $\left(\mathrm{R}-\mathrm{R}_{\mathrm{sw}}\right) / \mathrm{R}>0.25$ in the current condition $\mathrm{H} / h_{\mathrm{sw}}<0.856$ (physical model) and $\mathrm{H} / h_{\mathrm{sw}}$ $<0.802$ (numerical model).

The distance of the tsunami run-up range $\left(\mathrm{X}_{\mathrm{i}}\right)$ was directly proportional to the water storage height $\left(\mathrm{d}_{0}\right)$ in the reservoir. The higher the depth of the reservoir, the further the range of the tsunami run-up would be. In the physical model, the sloping beach scenario without seawall model with $d_{0}=30 \mathrm{~cm}$ produced maximum $X_{i}=$ $6,081 \mathrm{~m}$, while in numerical models also in the same scenario, it obtained maximum $\mathrm{X}_{\mathrm{i}}$ value $=6,970 \mathrm{~m}$.

\section{ACKNOWLEDGMENT}

We would like to express our highest gratitude to the Ministry of Public Works and Public Housing for the support through awarded scholarship during the academic period and so that this research study can be conducted and completed successfully.

\section{REFERENCES}

Arana, A. M. H. (2017) 'Wave run-up on beaches and coastal structures'. UCL (University College London).

Benazir, Triatmadja, R., Raharjo, A. P. \& Yuwono, N. (2016) 'Studi Interaksi Gelombang Tsunami terhadap Struktur Mitigasi dan Pengaruhnya dalam Pembentukan Run-up di Daratan Pantai. Semarang, in HATHI.
Benazir (2016) Usulan Penelitian untuk Disertasi: Pengembangan Metode Simulasi Run-Up Tsunami dan Aplikasinya pada Beberapa Kasus Tsunami di Indonesia. Yogyakarta.

Bock, Y. et al. (2003) 'Crustal motion in Indonesia from global positioning system measurements', Journal of Geophysical Research: Solid Earth. Wiley Online Library, 108(B8).

Bryant, E. (2014) Tsunami: the underrated hazard. Springer.

Cummins, P. R., Kong, L. S. L. and Satake, K. (2008) 'Introduction to "Tsunami Science Four Years After the 2004 Indian Ocean Tsunami, Part I: Modelling and Hazard Assessment"', in Tsunami Science Four Years after the 2004 Indian Ocean Tsunami. Springer, pp. 1983-1989.

Goto, C. et al. (1992) 'Numerical method of tsunami simulation with the leap-frog scheme', Translated for the TIME project by N Shuto.

Heller, V. (2011) 'Scale effects in physical hydraulic engineering models', Journal of Hydraulic Research. Taylor \& Francis, 49(3), pp. 293-306.

Holthuijsen, L. H. (2010) Waves in oceanic and coastal waters. Cambridge university press.

Imamura, F., Yalciner, A. C. and Ozyurt, G. (2006) 'Tsunami modelling manual', UNESCO IOC international training course on Tsunami Numerical Modelling.

Løvholt, F. et al. (2014) 'Tsunami risk reduction-are we better prepared today than in 2004?', International journal of disaster risk reduction. Elsevier, 10, pp. 127142.

Nakaya, N. et al. (2018) 'Effect of tsunami drill experience on evacuation behavior after the onset of the Great East Japan Earthquake', International journal of disaster risk reduction. Elsevier, 28, pp. 206-213.

Nateghi, R. et al. (2016) 'Statistical analysis of the effectiveness of seawalls and coastal forests in mitigating tsunami impacts in iwate and miyagi prefectures', PloS one. Public Library of Science, 11(8), p. e0158375.

Naylor, A., Walker, J. F. and Suppasri, A. (2018) 'Suitability of the early warning systems and temporary housing for the elderly population in the immediacy and transitional recovery phase of the 2011 
Great East Japan Earthquake and Tsunami', International journal of disaster risk reduction. Elsevier, 31, pp. 302-310.

Parwanto, N. B. and Oyama, T. (2014) 'A statistical analysis and comparison of historical earthquake and tsunami disasters in Japan and Indonesia', International Journal of Disaster Risk Reduction. Elsevier, 7, pp. 122-141.

Pile, J. et al. (2018) 'Can the risk of coastal hazards be better communicated?', International journal of disaster risk reduction. Elsevier, 27, pp. 439-450.

Raby, A. et al. (2015) 'Implications of the 2011 Great East Japan Tsunami on sea defence design', International Journal of Disaster Risk Reduction. Elsevier, 14, pp. 332-346.

Sriram, V. et al. (2016) 'Tsunami evolution and run-up in a large scale experimental facility', Coastal Engineering. Elsevier, 111, pp. 1-12.

Strusińska-Correia, A. (2017) 'Tsunami mitigation in Japan after the 2011 Tōhoku Tsunami', International journal of disaster risk reduction. Elsevier, 22, pp. 397411.

Suppasri, A. et al. (2012) 'Mapping of historical tsunamis in the Indian and Southwest Pacific Oceans', International Journal of Disaster Risk Reduction. Elsevier, 1, pp. 62-71.
Synolakis, C. E. et al. (2008) 'Validation and verification of tsunami numerical models', in Tsunami Science Four Years after the 2004 Indian Ocean Tsunami. Springer, pp. 2197-2228.

Tomiczek, T. et al. (2016) 'Physical modelling of tsunami onshore propagation, peak pressures, and shielding effects in an urban building array', Coastal Engineering. Elsevier, 117, pp. 97-112.

Triatmadja, R. and Nurhasanah, A. (2012) 'Tsunami force on buildings with openings and protection', Journal of Earthquake and tsunami. World Scientific, 6(04), p. 1250024.

Triatmodjo, B. (2006) Perencanaan bangunan pantai. Beta Offset.

Wang, D. (2015) 'An Ocean Depth-Correction Method For Reducing Model Errors In Tsunami Travel Time: Application To The 2010 Chile and 2011 Tohoku Tsunamis.', Science of Tsunami Hazards, 34(1).

White, I. and Haughton, G. (2017) 'Risky times: Hazard management and the tyranny of the present', International journal of disaster risk reduction. Elsevier, 22, pp. 412-419.

Yeh, H. H. (1991) 'Tsunami bore runup', in Tsunami hazard. Springer, pp. 209-220.

Yeh, H. H., Ghazali, A. and Marton, I. (1989) 'Experimental study of bore run-up', Journal of fluid Mechanics. Cambridge University Press, 206, pp. 563578. 
[This page is intentionally left blank] 